\title{
The Theory of Justice and Profit Maximization
}

\author{
Gennady Bilych \\ Dept. of Management, UPEC Corporation \\ Belgorod 20 Popova str., 308000, Belgorod, Russia \\ Tel: 7-472-220-2033Ｅ-mail: genatdht@yandex.ru
}

$\begin{array}{ll}\text { Received: February 18, } 2014 & \text { Accepted: March 8, } 2014 \\ \text { doi:10.5296/ber.v4i1.5139 } & \text { URL: http://dx.doi.org/10.5296/ber.v4i1.5139 }\end{array}$

\begin{abstract}
At present, all existing so-called theories of justice, except only for utilitarianism, divide the history of humanity into long years of hopeless night and a few minutes of long-awaited dawn. Any theory must be disregarded if it assumes that for centuries people have come to terms with their lack of freedom only because of mental limitations or an unusual strictness of the ruling elite. Of course, 500 or 1000 years ago, as is the case today, many people were dissatisfied with their position in society, but nevertheless the majority of the population of Ancient Egypt, for example, or the Roman Empire considered the established order to be entirely justified. Therefore any theories that are not able to explain historical changes to people's perceptions of justice must undoubtedly be deemed unrealistic and incorrect. Utilitarianism does not have this disadvantage, but it does have another well-known defect which has to do with the use of the strange and immeasurable concept of utility. It is rather difficult to give a logical explanation of how a concept that is so actively criticized and despised by many economists can continue to be the foundation of all economic science. In my opinion, to this day there have never been any significant barriers preventing the use of personal profit as the primary motive for human behaviour. This will not only restore the position of utilitarianism so undeservedly lost, but also provide an opportunity to solve a number of theoretical issues and will also fill with optimism the conclusions that follow from Arrow's Impossibility Theorem.
\end{abstract}

Keywords: Theory of justice, Profit Maximization, Arrow’s Impossibility Theorem

\section{Introduction. Is the Theory of Justice Part of Economic Science?}

I beg to differ with the opinion of Rothbard (1977) and many other respected economists that economic theory cannot be a source of ethical evaluations and recommendations. Rothbard believed that economists are obliged to maintain a position of ethical neutrality and under no circumstances should they be guided by value judgements. They should be interested only in economic processes; they should give recommendations and warn of the possible 
consequences of certain practical steps taken by governments and individual economic agents. Ethical assessments and questions of justice are areas of interest for specialists of other sciences. However, in my opinion, these arguments are wrong. Allow me to explain. If we assume that when taking economic decisions people seek to not only maximize their profit or utility, but are also guided by certain ethical principles that have nothing at all to do with maximization, this means that these principles have an effect on their level of wellbeing. If, when purchasing a particular item, a person does not choose the item that will provide more profit or utility, but which the person prefers due to ethical reasons, their level of economic wellbeing will, most likely, decrease. Furthermore, a decision such as this could provide an additional market advantage to a producer that is far from being the most economically efficient. As a result, the level of output of goods and services may be lower than it could have been. This means that the ethics and morals that the members of a certain society are guided by will be inextricably linked to the wellbeing of that society. The level of income of citizens of a country will depend on, for example, the principles of justice in effect in that country. Consequently, there can be no talk of ethical neutrality among economists. An economist can and must be concerned with issues of ethics, morals and justice, he or she can and must study them and he or she can and must give ethical recommendations and advice.

\section{Literature Survey. Discrepancies with Existing Theories of Justice}

In the latter half of the $20^{\text {th }}$ century there was a dramatic increase in interest among academicians and ordinary citizens towards problems associated with the occurrence and the spread of ethical norms, and moral principles and ideals in society. Theories of justice began to appear and spread like mushrooms after the rain. Quick success and global recognition lay in wait for their creators. This interest did not appear out of nowhere and was connected with the major political, social and economic changes that took place in virtually all four corners of the world. The world changed rapidly. Many countries became independent, the movement against racial discrimination grew, women began to play a larger role in politics and the economy, family values were reviewed, various youth movements and cultures were formed, and the attitude to sexual minorities changed. Major changes always cause people to seek out certain moral pillars and foundations, which do not allow society to be divided into sections and provide an opportunity to achieve some kind of social stability. Urgent answers to a great deal of questions were needed. What was happening? How should we react to this? What were the limits of freedoms? What is a fair society?

\subsection{Imaginary and Real Disadvantages of Utilitarianism}

At that time, utilitarianism, as a theory explaining human behaviour which gave entirely definitive answers to society's questions and completely dominated for more than a century, was under constant criticism. It must be admitted that much of the criticism was unfounded and was rather easily brushed aside by supporters of utilitarianism. The main claims of Rawls (1971) and other critics of utilitarianism (Frey, 1984; Harsany, 1982; Gordon, 1980; Hare, 1981) usually stated that in their opinion the theory allows the happiness of certain individuals to be sacrificed in the name of the happiness of the majority. Consequently, utilitarianism allows clear cases of injustice to exist in a society. For example, the profit obtained by slave owners 
may be rather high; therefore the overall amount of benefit may be higher in a slave-owning society. It would be this society that would be preferable according to the criteria of the maximization of utility. In the opinion of Rawls, this result makes utilitarianism absolutely unacceptable to any rational person. But this is a shot off target. In actual fact, I believe that it is a wonderful example in defence of utilitarianism. It finally convinced me of the superiority of utilitarianism over other theories because only utilitarianism is able to clearly indicate the causes of the long period of the life of hierarchical states and answer the question why the majority of people living at that time were completely satisfied with this. No other theory in the 1970s or today gives any logical explanation for the existence of slave-owning and feudal states in the past and also modern non-democratic countries, the majority of the population of which took and still takes the established order to be entirely just. It is naïve to assume that these countries existed and exist simply because of the utter weakness of the public and the unbelievable tyranny of rulers. In my opinion, the idea of North and Thomas (1973) is much more convincing. According to this idea, feudal institutions, such as serfdom are an effective contract between serfs and landowners providing protection in exchange for the labour of serfs on the landowner's land. Today, we may endlessly discuss the shortcomings of slavery and feudalism, but it must be recognised that they gave humanity the opportunity to reach a significantly higher level of goods production than in any preceding periods. In those times the choice was not between slavery and the freedom of today, but between slavery and a meagre existence in a primitive society.

Hundreds of pages of various books and articles are filled with such dubious accusations. Here is another similar example demonstrating, in the opinion of Hayry (1994), the absolute indifference of utilitarianism towards the fate and rights of individuals. The sheriff of a small town in which a terrible crime has taken place, after unsuccessful attempts to find the criminal, is forced to commit a clearly unjust act. In order to appease the outraged and frightened residents of the town, the sheriff charges a person who has nothing to do with the crime. By sacrificing one person, the sheriff makes everybody else happy. Hayry believes that this is what utilitarian theory demands. Is this correct? No, the utilitarian theory demands nothing of the sort. The case described would not contradict the arguments of the utilitarian theory if in the town there were only irrational, brainless and completely isolated animals. Thankfully, however, people are different to animals in the fact that they are highly rational, have brains, exchange information and constantly interact with one another. Every rational resident will be concerned with how the sheriff adheres to the law when carrying out his duties because anybody could be the person that is wrongfully accused of the crime. This means that everybody has a very definite chance of spending the rest of their life in the town jail, if the sheriff is allowed to break the law. In evaluating what happened, people will take into consideration all the possible outcomes for themselves. Utilitarianism does not require that the sheriff break the law, but rather that he strictly follows existing legislation. Furthermore, the very fact that events such as these do sometimes happen in real life is further supporting evidence in favour of utilitarianism. Utilitarianism readily allows the existence of dishonourable sheriffs in the event of limited access to information in the town, for example, disunity of the town's residents, a lack of political activity or a lack of control in the judicial system. 


\section{Mll Macrothink}

Business and Economic Research

ISSN 2162-4860

2014, Vol. 4, No. 1

Such attacks on utilitarianism are quite easy to fend off, but this theory does still have an Achilles heel. It is a social contract that allows a large and a small number of citizens to avoid serious conflicts, live together in the same area and pursue their own personal objectives. This type of contract is not put down on paper and nobody signs it, but it undoubtedly exists and has existed at all times and in all societies. No tribe, town or country can exist and develop stably without it. A social contract involves rules of human behaviour that people follow or try to follow on a daily basis when performing certain acts. The problem of utilitarian theory is that in a society of individuals seeking to maximize their utility, a contract such as this is not possible. The process of public voting will inevitably arrive at a dead end, and only a dictator will be able to provide a way out. The voting of free individuals will continually generate cycles (Arrow, 1951; Kramer, 1973), therefore in a democracy it is not possible to have a vote that will satisfy everybody. These rather unfortunate conclusions of the utilitarian theory were no secret even in the $19^{\text {th }}$ century. Mill ([1861], 1979) was aware of the obvious weaknesses of the principle of "maximum happiness" proposed by Bentham ([1789], 2005), and attempted, albeit unsuccessfully, to save utilitarianism. His proposal to maximize happiness not from case to case, but in the long term, and his division of pleasures into higher and lower look unconvincing and will not pass the reality test (Sandel, 2009). The arrival of Arrow's famous work (1951) revived the interest in this problem, the essence of which lies in the irregularity of human desires, which causes an inability to compensate for the losses of some members of society at the expense of the benefits of others. If the utility obtained by a certain individual was measurable and comparable to the utility of other individuals, it would not be very difficult to reach an agreement and conclude a social contract. Rules and norms of behaviour would be established whereby the total level of utility would reach a maximum point. Individuals who increased the utility obtained as a result of the adoption of a new law, for example, could easily compensate for the losses suffered. As a result of the exchange of utility, the situation for everybody would improve and the law would be adopted. However, the immeasurability of utility very often leads to a situation similar to that described by Sen (1970), when Prude, a virtuous citizen, and Lewd, a libertine, are unable to agree on reading the book Lady Chatterley's Lover.

\subsection{Disadvantages of Other Theories of Justice}

For other theories of justice, the problem of the social contract is, in my view, more serious and less easily solvable. Not only do absolutely all theories suffer from hidden utilitarianism and inherit its well-known defect, but their own mistakes also cause a number of additional problems.

Dworkin (1977) was absolutely correct when stating that Rawls' initial contract under the conditions of a veil of ignorance (Rawls, 1971) is not only a weak type of contract, but not a contract at all. For the stability of society, it is of critical importance that each and every one of us is prepared to consider the contract fair, not only under conditions when we know nothing about our own talents and capabilities, but also under real conditions when everybody knows everything. Otherwise, many educated, successful and talented people will believe that their rights are being violated and they will try to change the established order. It is clear that we all, on a daily basis, when performing various actions and participating in a number of acts of 
exchange, evaluate the laws, rules and regulations in effect in society. These evaluations are carried out not under a veil of ignorance, which is essential for concluding a social contract in Rawls' theory, but under conditions when every individual knows their place in society, their talents and what their future capabilities may be. Whether or not the established laws, rules and regulations are kept depends on these daily evaluations. If the majority of citizens believe that the established laws, rules and regulations are not just, then sooner or later they will be changed. This is exactly why Rawls' theory, based on the extremely dubious idea of the hypothetical initial contract, does not pass tests at a micro level. Just try and imagine, as Nozick (1974) suggests, a workforce in which the abilities of individuals, as Rawls recommends, are placed under common patrimony! This is clear exploitation of certain people by others! Rawls' doubts of the capability of people to conclude a social contract under real conditions and not only under a veil of ignorance are completely unfounded. It is quite clear that there are many examples in real life when mature individuals with life experience are in a condition to establish fully functioning laws and regulations that satisfy everybody. Pirates had their own set of laws, each member of the crew performed specific functions for which they were responsible (Leeson, 2009). For breaking the law or failing to perform their duties, all pirates faced severe punishment. This helped to create a formidable and efficient team adept at robbery. Throughout most of human history there has been a continual process of development and settlement on new lands. People from opposite ends of the planet formed societies large and small, created laws and observed accepted rules of behaviour. Despite Rawls' assertion, in order to do so they did not require an initial contract under a veil of ignorance. Rational people need nothing more than common sense in order to establish rules and regulations that suit everybody or the vast majority of society.

With Nozick (1974), matters regarding the social contract are no better than with Rawls. I indeed strongly support his desire to minimize state functions, but it must be understood that a limited state was not always and not in all cases the best form of social contract. Nozick's ideas would never have received support from ancient tribes of hunters and gatherers. If his cries of "Down with the leader! Long live freedom!" were heard and supported by the members of a tribe, they would most likely not live for a long time at all. They would not only die at the hands of members of hostile tribes, but they would also starve. Life as part of a tribe was not only much safer, but also more nourishing. Morally justifying the existence of a minimal state is reasonable in modern times, with the current level of economic development, but it was not at all reasonable to do so in the distant past. Nozick's moral rights are no better than believing in God (Gauthier, 1985) because it remains completely unclear what his boundless faith in the minimal state is based on.

Gauthier (1985) does not hide the connection between his theory of justice and utilitarianism. Gauthier assumes there are rational motives in all individuals, but for some reason in his concept they must seek to maximize common utility. Gauthier does not believe in the free market and proposes supplementing it with cooperation because, in his opinion, cooperative behaviour enables more to be achieved. This is by no means always the case and furthermore, very often, cooperation causes much more harm than good. One only has to recall the actions of Soviet cooperative enterprises and collective farms, which nobody would think of calling a 
success. Even Gauthier himself would most likely prefer several independent sellers, rather than a single trading monopoly. His belief in cooperation, as with Nozick's belief in a minimal state, is no better than belief in God.

Communitarianism copes rather well with the explanation of the existence of different perceptions of ethical norms and moral principles in different societies (for example: MacIntyre, 1984), but is utterly helpless when it comes to explaining how such societies can successfully cooperate with one another. Walzer (1983) is certainly correct in asserting that the rules of justice in any country are connected to its history and culture. However, giving this exclusive attention is not only unwise, but also dangerous. The theory of justice, based on the ideas of a common beginning, cultural traditions and shared history, is not as harmless as it may seem at first glance. The theory can be used to quite easily justify the undesirability of any changes in a society, including national, cultural and religious changes. At the present time, with increasing migration processes and as ethnic compositions, religious beliefs and cultural traditions are changing rapidly in many countries and regions, this theory may seem rather appealing and attractive in the eyes of radical nationalists or extremely conservative citizens and could become a major weapon in their hands. One can only hope that communitarianism will never be able to gain a significant number of followers and the life span of such theories will be very brief.

It must be recognised that all theories of justice existing today, including those which have not been talked about, cannot be thought of as significantly credible for two reasons. Firstly, it remains entirely unclear how a social contract is concluded. What is it based on? What wishes and desires of individuals allow this to be done? How do people ethically assess different events? Why do these assessments usually coincide? Secondly, all theories, except for utilitarianism, exclude any changes in the time of people's perceptions of justice. But such changes do take place. This is clear. Many laws, rules and regulations, which used to be thought of as good, are now seen as extremely negative and vice versa. Much of what is thought to be fair today, will no longer be so in the future. Consequently, all theories of justice must be rejected because they are not able to explain the existence of a social contract and historical changes to laws, rules and regulations. However, I do not believe that everything is so dismal. I am certain that utilitarianism, which is based on the human desire for profit, may provide clear answers to any questions and I will attempt to prove this.

\section{Theory of Justice}

\subsection{Which Questions Must a Theory of Justice Answer?}

Any theory is only worth attention and discussion if it does not contradict clear facts and gives correct answers to events that have happened in the past and are happening today. Therefore, for further discussion it will be useful and rather easy to formulate a number of simple criteria of realism which a theory of justice must demonstrate. In my opinion, these criteria are as follows.

The theory must explain changes in people's perception of justice that take place and have taken place throughout the entire period of human existence. Only a few centuries ago, people 
acquiesced to the ruling of a king, czar, feudal lord or emperor and believed the established order to be fully just. According to Aristotle, a fair society is a hierarchical society where equality is only possible for equals and those not equal should be satisfied with inequality. If a superior hits you, you should not hit back. However, if a superior is hit then the perpetrator should not only be hit back, but severely punished. A man should rule and a woman should unquestioningly obey him. Usury is evil; it is not fair to demand interest, money should not create money. The majority of Aristotle's contemporaries would have agreed with these words and this should not come as a surprise to anybody. This is what people believed justice to be. But then everything rapidly changed. Suddenly people were no longer satisfied with the laws and regulations that had ensured order and stability for centuries. People began to demand change; people began to demand new laws and regulations that were completely different to those of the past. A theory of justice must certainly be in a condition to explain such changes. Otherwise it is infinitely far from the truth.

Freedom does not have to be an unconditional sign of justice. This is closely related to the previous criterion, but, in my opinion, it must still be highlighted. There is a good reason for this. For some reason, many people consider freedom to be a natural and unconditional human right. Almost no one would argue with the fact that the desire for freedom in each and every one of us is laid down by nature itself, we are born free and value freedom above all else. As expressed by Rawls (1971), human rights can neither be subject to political bartering, nor be a bargaining chip in the calculation of public interests. We will never agree to be happy slaves or gracious subjects of a feudal lord (Sen, 1999). However, what is this certainty based on? Not too long ago most people living in Europe were subjects of feudal lords; they did not protest against this and perhaps many of them were even quite happy. Why is it so that many countries have not yet become developed democracies? Why do we often consciously seek to limit our freedom, by entering into marriage for example? What causes us to be subordinated to a manager at work or follow the orders of a commander in the army? I believe that our attitude towards freedom is like this simply because we happen to live today and not 500, 1000 or 3000 years ago, when achieving freedom usually meant immediate death by starvation or murder at the hands of the enemy. Today freedom certainly allows one to achieve a great deal; democracies demonstrate impressive economic results. But this was not always so. In the past it was often the case that not societies with the most freedom, but societies with the strongest rulers occupied the top positions. And this power was praised, glorified and supported by the majority of the population.

A theory of justice must predict the future, in any case it should be able to point to possible changes in laws, rules and regulations that will most likely happen in the future. Will the market really continue to force out more and more non-market rules, as feared by Sandel (2012)? Will child trafficking and the sale of human organs become a normal and everyday occurrence? Will governments start to recruit more foreign citizens in order to carry out military action? How reasonable will it be to offer and purchase citizenship and what will the attitude be towards this in the near future? Will copyrights continue to be observed? Of course, a theory of justice is not able to give a definite answer to all questions, but it must be able to express certain assumptions and justify them. 
A theory of justice must explain the existence of different laws, rules and regulations in different societies. Why are there countries that are not free? Will they become free? Why in such countries does religion have such a strong influence? Should the laws be the same in all countries? Following the logic of Rawls (1971), Nozick (1974), Sen (1999) or Shapiro (2012), one must assume that when a social contract was concluded in certain countries, something went wrong. Rules and regulations were established that in no way served the interests of the majority. Perhaps MacIntyre (1984) was right in saying that laws are very closely linked to the history and culture of a society. However, in this case it remains unclear how changes occur in these laws and why they occur. For what reason do the laws, rules and regulations in modern Japan differ so greatly from the laws and regulations of modern China? If this has to do with the difference in history and culture in these countries, then why is freedom valued in South Korea and not in North Korea? We are entitled to demand answers to these questions from a theory of justice and if there are no answers, then there is no theory.

A theory of justice must be based on the desire of individuals to meet a certain objective. In my opinion, the idea sounds very strange that individuals, when creating institutions and laws, seek to minimize risk and uncertainty (North, 2005), when establishing a fair society they try to be honest (Rawls, 1971), when they purchase goods they maximize utility and when selling products they maximize profit. If people's desires are so diverse, then it remains completely unclear as to why, when creating institutions, they do not take into consideration the possibility of obtaining a certain profit and when selling a product they do not always strive to be honest. It would be far more logical to assume that when solving all the various issues they face, people attempt to pursue all goals simultaneously. However, if this is the case, we will have to admit that they will not be able to resolve any of the issues they face. Solving any problem will become an intricate puzzle. As I already noted (Bilych, 2012), an individual such as this would most likely require urgent psychological care if they attempted to purchase a computer which they intend to use both for pleasure and for work. In attempting to pursue multiple goals at the same time, the individual will not be in a position to perform a task that is this simple. What should the individual maximize in this case? Profit or utility? If they are looking for entertainment, they should maximise utility. However if they wish to use the computer for work, they must maximize profit. Therefore every trip to the shopping centre would simply lead to a nervous breakdown and a split personality. But what will happen with the individual if they try to minimize risk, avoid uncertainty and act honestly? It is most likely that this individual will suffer immediate clouding of judgement and a quick death. Therefore, in order to give humanity the opportunity to continue its existence, we have to determine the one goal that humans strive for. Naturally humans must pursue this goal when solving ethical problems, and when attempting to create institutes, and when at work, or when going shopping. It should also be remembered that this goal must enable individuals to conclude a social contract that all citizens are prepared to support, or the majority of them at any rate. What kind of goal is this? What do individuals strive for? Let us attempt to provide an answer.

\subsection{Do Consumers and Producers Exist? How Can Goods Be Divided into Consumer Products and Factors of Production?}

Modern economic science argues that there is no link between the processes of production and 
consumption; in textbooks, the chapters on the behaviour of producers and consumers are at a respectable distance from one another and in no way linked to each other. Economists believe that an average person, when purchasing apples or a car, attempts to maximize their utility. However, if tomorrow this person opens a restaurant and becomes an entrepreneur, all their goals and desires instantly change in the most unexpected manner. This person, and it might come as a surprise even to them, will all of a sudden discover that now, when purchasing apples or a car, they are obliged to obtain a profit. Such changes in human consciousness surprise not only ordinary citizens, but also some economists. As noted by Machlup (1971), if we assume that consumers maximize utility, then there can be no grounds to believe that firms managing such consumers must seek to maximise profit. However, these doubts have only been expressed by a few economists; the majority confidently insist that consumers and producers are completely different people. Therefore, in order for each of us to feel comfortable and confidently maximize what we need, it is extremely important to identify the main differences between consumers and producers.

In the view of authors of textbooks on microeconomics (for example: Samuelson \& Nordhaus, 2004), the main differences between consumers and producers is that consumers buy finished goods and sell factors of production, whilst producers sell goods and buy factors of production. However, I believe there are at least two reasons to doubt that this statement is true. Firstly, producers may sell not only goods, but also factors of production, to other producers for example. They may buy not only factors of production, but also finished goods. Consumers may sell not only factors of production and buy not only goods. Secondly, I am always amazed at the very persistent attempts to divide all benefits into consumer goods and factors of production, which very often is virtually impossible to do. Try to name at least ten exclusive goods or exclusive factors of production. This is no easy task and will most likely be impossible. Is land always a means of production? What are cars, petrol, electricity, computers, tables, books or spanner? In one case they are goods and in the other they are factors of production. A natural question arises: why divide them at all? What is the reason for dividing products into final and intermediate products? What is the point? Yes there are intermediate and final goods and the same product can in one case be a final product and in another case an intermediate product. I believe that these grounds are not sufficient to divide people into certain groups and give them different objectives.

Since economic textbooks cannot clearly indicate the goal which I must pursue, I will try to do it myself. Who am I, a consumer or a producer? For many of us it will be rather difficult to give a definitive answer to this simple question. We are all consumers, and in all likelihood nobody would dispute this. However, few people would agree that we are all producers. This is strange because in order to consume something, we have to produce it first, otherwise there will be no means to purchase goods or services. Consequently, any person is always both a consumer and a producer. We are still producers even when we are employees. We only agree to become employees at a company when the salary offered is greater than the income we could earn working independently. This means that when working in a firm, we produce more. This measure also spares us the risks and uncertainty, which are inherent in entrepreneurial activity. As a reward for their labour, an employee receives the product they produce, in the form of 
money of course. The entrepreneur also receives a reward in the form a produced product. They then go on to exchange their produced products for goods, services, capital goods, or resources. In other words, people voluntarily come together for joint production activity, some of them take on risks and manage the production process, the others are directly involved in production and after a product has been produced, they all go down to the market where they meet with other producers and carry out a mutually beneficial exchange. What are the main differences between consumers and producers? Why do some of them maximize profit and others maximize something unknown, a certain immeasurable and vague utility?

All the above inclines me to believe that I am both a consumer and a producer. In order to avoid splitting my mind in two and becoming a regular client at a mental institution, I will still need to define the single goal that I must pursue.

\subsection{Maximization of Utility or Maximization of Profit?}

The concept of utility first appeared approximately 300 years ago when the fundamentals of the theory of probability were being established and it is deservedly associated with the mathematician Bernoulli ([1738], 1954). Later, thanks to the efforts of the English philosopher Bentham, the economist Jevons and their numerous followers, utility became firmly and successfully rooted in economic science. How could it be so that a member of such a high-standing family of Swiss mathematicians could need such a vague concept to explain human behaviour? Bernoulli believed that people associate the value of any object with the benefit they can gain from it. It seems that it would be logical for the mathematician to use a concept such as profit as a benefit. However, for some reason, Bernoulli preferred to use utility. In my view, there are two reasons for this. Firstly, in the early $18^{\text {th }}$ century in Europe and other parts of the world, barter was still the most popular form of exchange and the money economy was only just beginning to win its right to life (Braudel, 2011). At a time when large-scale production did not yet exist, when the use of hired labour was rare and irregular and steam engines had only just begun to appear, the meaning of the word profit raised no fewer questions than the meaning of the word utility. Secondly, Bernoulli discovered what later became known as the law of diminishing marginal utility. An income of a one thousand ducats means more to a poor person than to a rich person, although the monetary value is the same for them both. The benefit or utility gained from earnings are inversely proportional to current wealth. Somebody has a capital of 100,000 ducats and somebody else has the same quantity of half-ducats. If the former earns 5,000 ducats and the latter the same amount of half-ducats, it is quite clear that for the former a whole ducat will be the same as a half-ducat is to the latter. This means that different people value different profits in the same way. However, if you think about it, this in no way rejects the possibility of using profit rather than some kind of utility as a motive by which humans make decisions. Both the poor person and the rich person will value their earnings in the abovementioned example in the same way because the profit rates in these cases are equal $-5 \%$. In other words, the effectiveness of their cash investment is the same. Obviously, in order to evaluate any economic activity the key criterion for any individual is the effectiveness of decisions made, therefore it is the profit rate that is most important, not the absolute value of profit. A person acts rationally because having determined the most effective method of investing money, they will have the opportunity to invest additional funds. 


\section{Mll Macrothink}

Business and Economic Research

ISSN 2162-4860

2014, Vol. 4, No. 1

Therefore, after having invested a considerable sum of money in the most profitable project, the individual will be able to obtain maximum profit.

Using the principle of maximization of utility to explain human behaviour has never caused much excitement among economists. Utilitarianism, according to Payne (2006), is both despised and widely used. The reasons for this are well known. Utilitarianism is a relatively consistent theory based on a simple measurement of preferences, which is what makes it attractive. A moral evaluation of any event arises from an arithmetic calculation, however in order to obtain an overall result, we have to measure the preferences of a single criterion (Sandel, 2009), which, in the opinion of many is virtually impossible. The overwhelming majority of economists currently doubt the measurability of utility and this is no surprise. How can you measure something that nobody can clearly define? How can you calculate happiness, satisfaction or a lack of suffering? These same issues at one time were of great concern to Moore (1922) who attempted to create a conceptual revolution in utilitarianism. He proposed using the word benefit instead of utility and the expression "maximum net sum" instead of "greatest happiness for the greatest number of people". Unfortunately, however, people did not listen to Moore. But if you do listen to him and take the next logical step and replace the word benefit, which no economist can give a clear definition of, with profit, then everything immediately falls into place. Profit can be measured and compared, it is able to compensate for losses incurred and therefore allows the existence of a social contract.

Today, very few would object to the fact that consumers fairly often seek to maximize profit and not utility. It is impossible not to agree with Simon (1971) who argues that consumers gather certain information until the point when gathering additional information becomes equal to the marginal profit that may be obtained as a result of possessing that additional portion of information. I believe that the ideas of Becker (2003) seem so clear and convincing for the very reason that in order to explain human behaviour, he normally uses the words profit and benefit and only very rarely the word utility. A person will obtain further education to the point where their marginal costs are equal to the profit they will obtain in the form of a higher salary. A criminal will stop committing crimes if their marginal costs are greater than the amount of criminal proceeds or profit. Discrimination against ethnic minorities only exists because many representatives of the majority obtain an economic benefit from discrimination.

Under what circumstances does a person maximize only utility? Perhaps this occurs when a person buys food, goes to the theatre, looks after children or trains in the gym. Perhaps it applies to those cases where a person is simply trying to live normally. However, in order to function normally, a firm or company also needs water, electricity, stocks and raw materials on a daily basis. Furthermore, companies very often take care of their employees, holding sports competitions and social events. On these grounds, nobody would think of arguing that companies and firms sometimes attempt to maximize utility. Of course, a person may prefer to consume green apples, rather than red apples, they may love music and spend all their spare time playing golf. But what does this change? We are not going to accuse producers of being irrational and challenge their desire for profit only based on the fact that they conduct charity events, paint the workshops in a different colour, or plant fir trees around the production plant. 


\subsection{Utilitarianism Based on Maximization of Profit. A Market Triumph}

What should our attitude be towards violations of intellectual property rights? Should the law protect the observance of such rights on the Internet and how necessary is it? Should a person who uses another person's ideas without the permission of the author always be subjected to moral condemnation? It is not too difficult to answer these questions if we consider people's desire for profit, but it is completely impossible if we believe that people maximize utility. Many years ago, Coase (1988) very clearly demonstrated the way in which people solve the problem of the effective distribution of rights. Rights to something are normally granted to the individual who can obtain the maximum benefit from such rights. In this case, Coase deliberately preferred to use the word benefit and not utility. Benefit is something more real and material than utility. Coase hoped that the benefit of one individual would be able to be compared with the benefit of another individual and, most importantly in terms of the effective distribution of rights, benefit allows compensation to be paid. And in Coase's examples compensation of individuals can only be paid from profit obtained. Of course, in this case the benefit is nothing other than profit. If a certain person or group of people can obtain a higher profit by introducing a new device, for example, than the owner of the invention, then this person or group of people will offer the owner sufficient compensation in exchange for the opportunity to use the invention. If the creator of the invention is independently able to make better use of their property than others, they will continue to own it alone. The refusal of a creator, for certain reasons, to agree to conclude a profitable deal has no effect on the final distribution of rights. An inefficient inventor will have less funds to protect an idea from the encroachments of third parties than those individuals seeking, lawfully or unlawfully, to acquire it. Therefore, however much we try today to defend copyright and increase liability for its violation, in the future these rights will to a certain extent be increasingly violated, which will lead to the adoption of more liberal laws. Many people already have a rather tolerant attitude towards violations of copyright law in the field of medical drugs, and scientific books and journals are increasingly appearing in the public domain. Very soon society will support more liberal laws governing intellectual property rights and will consider them fair because more efficient owners can offer society higher profits and higher economic growth. In this example we can easily see that utilitarianism based on maximization of profit explains the historical changes in people's perception of justice, does not consider economic rights and freedoms to be an unconditional sign of justice, predicts the future and is based on well-defined desires of individuals.

The most obvious and important conclusion that follows from the above is that in countries with a market economy, absolutely all market solutions should be considered fair. A free market is fair because it is effective and its decisions lead to the maximization of personal and common profit. Of course this statement is only true when a market exists, when decisions in it are made freely and when there is no disruption to its function. The last observation is very often forgotten by numerous critics of a market accusing it of immorality and injustice. When Sandel (2012) doubts the fairness of market decisions in cases of making profits on medical care vouchers in China or the trading of free tickets to see Shakespeare plays in New York's Central Park, he overlooks the circumstance that these examples are in no way connected to the 
function of a free market. In these cases there is no market and the people are outraged not so much at the trading of vouchers and tickets, but rather at the fact that the government was not in a position to provide them with the required amount of public goods. Having paid once via taxes for the services of a doctor or to see a show, people are forced to pay again for the provision of public goods.

People most often have two main complaints against the market. Namely the violation of the principle of equality and the inaccessibility of certain goods for poor people. However, in my opinion, these charges are not being addressed to where they should be. I very much doubt that a queue facilitates equality and distributes goods in a fairer manner than a market. If a person is willing to pay a certain amount of money and move forwards, this means that they place a higher value on the goods offered than others. The quantity of the goods does not decrease and the same number of citizens can still purchase them. Furthermore, if we give the market the opportunity to function freely, the quantity of goods increases and their prices decrease. They will be purchased by a greater number of citizens and they will become more affordable for the poor. The inaccessibility of goods for the poor is associated not with the function of the market, but primarily with the lack of a market and also an insufficient level of development of the economy and labour productivity.

If the owner of a hardware store listens to the advice of Kahneman, Knetsch \& Thaler (1986) and does not increase prices on snow shovels after a snowstorm from $\$ 15$ to $\$ 20$, this could mean that a shovel would go to a person who needs it to clear a garden path and not to a person who urgently needs to clear snow from their car and take their child to hospital. Considering such a scenario, accusing the market of injustice will no longer seem so fair to many people. It is fair when a limited number of shovels are obtained by the people who need them most of all and not simply those who were first in the queue. A rational hardware store owner will not raise prices on shovels, if there is a sufficient amount in the warehouse, as the owner will primarily be interested in selling as many shovels as possible. The owner will certainly raise prices if there are not enough shovels to satisfy the demand. This means the store owner will receive the maximum possible profit, the sick child will be taken to hospital and the garden path may remain covered in snow.

However, one question remains unanswered. What if the parents of the sick child do not have $\$ 20$ for a snow shovel or enough money to pay for the services of a doctor? Can people who seek to maximize their profits solve such problems? Yes they can and they do. As surprising as it may sound, people only have this ability due to their eternal and irresistible desire to make profit. The next section will examine these unexpected qualities of rational people.

\subsection{Arrow's Theorem}

What goal does Robinson Crusoe pursue on the desert island? Of course, he primarily tries to survive and return home as soon as he can. However, what is interesting is what does he maximize in this case? I do not know about anybody else, but I have no doubts in this regard. Robinson undoubtedly seeks to obtain the maximum possible profit. Every day he exerts a certain amount of effort and spends a certain amount of time on providing food, clothes and shelter for himself. His main aim is to increase the quantity and quality of goods consumed. In 
other words, Robinson strives towards the highest possible value for the goods he consumes. This means that his aim is to achieve a higher value for the goods he obtained and produced today than the goods that he consumed yesterday. In the language of economists, the difference between the value of products produced and the value of resources expended is called profit. Therefore, Robinson is seeking to maximize the profit obtained. The amount of profit depends solely on his skill, effort, luck and the weather conditions. Robinson Crusoe is not burdened by any ethical norms or moral principles at all. He has no need for them and there is no point in them. He always acts fairly because his actions have no effect on other people. To build a home, he can use rare and valuable types of trees, for food he can consume endangered species of fish and animals and he can make clothes from the fur of pandas which are listed in the International Red Book.

A great deal changes for Robinson Crusoe with the arrival of Friday on the island because this could have both a positive and negative effect on his profit. If Friday starts to hunt and fish in the same areas where Robinson normally hunts and fishes, the situation will clearly become worse for Robinson. His profit will decrease or he will even start to incur losses. However, if Friday goes to gather nuts and starts to exchange them for meat or fish obtained by Robinson, the situation will considerably improve for them both. Their profits will increase and the relations between them will become more peaceful and may even develop into a real friendship. It is for this reason that ethics, morals and justice come into play when there are two people who have to work together. Laws, rules and norms of behaviour are established which should help to increase the profits of both Robinson and Friday. Of course, there are absolutely no grounds to assume that these laws, rules and regulations will necessarily provide freedom to individuals. The laws, rules and regulations themselves limit freedom; there is no absolute freedom in the society. Only Robinson alone on the desert island has absolute freedom. Furthermore, if we assume that on the island there are few animals and plants and Friday is physically weak and does not have useful skills or abilities, the relations between him and Robinson will most likely not be equal. A hierarchical society may appear on the island. It may well be the case that Friday will not object to this, as a loss of freedom will enable him to survive and his profit will increase. Robinson and Friday will consider this to be a fair society, which naturally does not rule out occasional disagreements and conflicts between them. There could be far less disagreements and conflicts if Robinson and Friday begin to worship the same god. The emergence and spread of religion is very likely in a hierarchical society because it promotes the peaceful resolution of conflicts and the stability of a society based on inequality.

After some time, the hierarchical society on the island may be replaced by a democracy. If Friday becomes stronger and more resilient and acquires new skills and abilities, then his achieving freedom could be of benefit not only to himself, but also to Robinson. Robinson will no longer need to constantly control Friday, force him to work hard and continuously look for hiding places where Friday conceals the fish and nuts he has found. It will be of far greater benefit to him if they work independently during the day and meet in the evening at the edge of the forest to exchange nuts and fish for meat and milk. Democracy on the island will not completely eliminate disputes and conflicts, but it will help to reduce their scale to an acceptable level. 
If Robinson wants to cut down some nut trees and plant wheat on the plot of land cleared, he will have to pay compensation to Friday for possible losses incurred. If the loss of a few trees brings profit to all members of the society, the wheat field will be created. If the nuts bring Friday a greater profit than the wheat brings Robinson, the trees will continue to stand in their place. Friday will be able to compensate Robinson for the benefits lost and there will be no wheat field on the island. Any conflicts on the island could, of course, be resolved in this manner. Any conflicts not only on the island, but also in a society, country or vast region could be resolved in this manner.

Arrow (1951) was wrong when he claimed that a social contract is not possible in a democracy. Such a contract is quite possible and no dictator is required. People seeking to make profit are in a condition to conclude a social contract and this contract will establish the laws, rules and regulations that enable the maximum total profit to be obtained. This means the people choose the most effective method of economic management. Consequently, the level of output of goods and services in the society reaches its maximum levels. It is important to note that there are absolutely no obstacles preventing a social contract from being unanimously adopted. If a contract proposes not only compensation for all the losses incurred by it, but also a certain level of profit for individuals affected, everybody will vote for it. In the real world, however, everything is slightly more complicated than in theory. People do not always establish laws that bring profit to all members of society. It is often very difficult to calculate all of the possible outcomes of decisions made. For example, laws in the US, England, France and Russia establish completely different levels of taxation. Which of these levels is fair? Not only ordinary citizens of these countries, but also numerous specialists are unable to provide a plausible answer to this question. The formation of public institutions is a lengthy and complicated process. As noted by Schneider (1963), the overall scheme of institutions does not develop in somebody's mind, institutes cannot be planned, people create them by method of trial and error. The ideal is, of course, unattainable, but it must be noted that it is in fact possible to get very close to it.

It is now time to return to the problems of the father of the sick child who does not have $\$ 20$ to purchase a snow shovel. Why does society feel obliged to help parents in such a situation? What profit do people maximize in doing so? At first glance, society gains no benefit offering help to parents. But this is not the case, people certainly do obtain a profit. I acknowledge that a neighbour who gives his shovel to the father of the child is acting out of unselfish and noble motives. The same is true for a hero fighting for and defending the interests of his country. They commit such acts and we admire them because these acts comply with the norms and rules approved by society. However, society itself does not act as unselfishly as it may seem when supporting the actions of the neighbour and praising the hero. People who are members of that society will certainly profit from such acts. They will receive their profit in the same way as Robinson does when he looks after Friday, who received an injury, for example, when climbing a tree. Friday's recovery will enable Robinson to continue to conduct the mutually beneficial exchange that brought them both profit. Furthermore, Robinson cannot rule out the fact that he too may become sick or injured in the future. Therefore his help is not selfless and he hopes that in the future Friday will act in the same way. All members of a large society also 
receive a very definite benefit from helping the parents of a sick child. They are saving a child who in the future may very well bring profit to the society as a whole and to each individual one of them. In saving the child, they hope that society will do the same if something similar happens to them.

\section{Issues of Justice in Real and Imaginary Examples}

How can we fairly resolve the dispute between Prude and Lewd about reading the novel Lady Chatterley's Lover, as described by Sen (1970)? On whose side should the laws, rules and regulations be? The real story of the publication of Lady Chatterley's Lover was in fact very similar to a heated and long dispute between two irreconcilable parties. This racy novel was first published in 1928 in Italy and later in France, however it was banned in Britain for a long time as it was thought to be a threat to public morality. It was only in 1960, when the sexual revolution had begun to gain momentum, that the publisher Penguin, after winning a high-profile lawsuit, was able to print the book in London. All copies of the book were completely sold out within 15 minutes and in order to satisfy the demand, the printing press had to be operated at full capacity. There is nothing unusual about this story. Changes in public taste such as these are quite easy to understand, if we proceed from the assumption that established laws, rules and regulations provide individuals with the maximum possible profit. Strong family ties and limited rights of women at the beginning of the $20^{\text {th }}$ century were needed for both men and women. Long working hours and hard physical labour meant that men could not do ordinary household chores. Looking after the home, preparing meals and bringing up children also required a great deal of time and considerable effort, which is why a man so needed a faithful and devoted wife. Women were in no less need of a strong family. They devoted almost all of their time to family affairs and they did not usually have any spare time to earn any money. For this reason, the man was often her only source of income. This meant that having a strong family was of benefit to everybody. This is why society paid close attention to the behaviour of married women and was not interested in giving them greater freedom. Society had a rather tolerant attitude towards a husband's infidelity, however, as this enabled many women, who for a number of different reasons did not have family ties, to receive an income. However, by 1960 much had changed. Many new appliances were developed to look after the home and prepare meals, state and private schools and nurseries assumed partial responsibility for the upbringing and care of children. Women began to no longer depend on their husbands, they now had the opportunity to receive a full education and go out to earn money. A new army of additional workers flooded the economies of many countries, which helped to increase the output of goods and services. Every member of society drew a certain amount of benefit from all of these changes; therefore society supported new laws, rules and regulations for the expansion of the economic and political rights of women. Women gained freedom and society stopped monitoring their behaviour so closely. Given all the above, I can, without a shadow of a doubt, fairly resolve the dispute between Prude and Lewd described by Sen (1970). Today they should both be allowed to read the book. It will not be of any threat to public morality. Reading books, magazines and newspapers contributes to the comprehensive development of an individual, raises their level of knowledge and helps to obtain a variety of information, which enables people to act more efficiently and therefore contribute to the 
economic prosperity of a society. I do not believe that Lady Chatterley's Lover should have been banned in 1928. However, 200 or 300 years ago this novel would have certainly been a threat to society and it would need to be banned, although it is unlikely that in those times anybody would have even thought of writing such a novel.

Following on from this, in order to assess the capabilities of my proposed approach based on the maximization of profit, I will attempt to choose examples and situations from the vast amount of literature available that have always caused the most difficulties in discussions and continue to do so. Let us begin with a real story described by Sandel (2009). In the summer 1884, four English seamen: a captain, a first mate, a sailor and a 17-year-old cabin boy, survived severe weather conditions, but were left without food or water in a lifeboat in the South Atlantic. Their vessel had capsized during the storm and there were virtually no chances of being rescued. On the $19^{\text {th }}$ day of starvation and torment, the captain suggested drawing lots to determine who should die so that the others could live. But the sailor refused and no lots were drawn. By that time, the cabin boy had become seriously ill and it seemed as if he would die at any moment. The following day the captain suggested killing the dying cabin boy, which he immediately did with the silent agreement of the first mate and the sailor. For the next four days they fed on the flesh and blood of the cabin boy and on the $24^{\text {th }}$ day help arrived unexpectedly. They were picked up by a ship that was passing by and brought back to England. In England they were arrested and tried. The sailor turned state's witness. Imagine if you were the judge examining this case. How would you rule? How would you act fairly? Should the captain's actions be justified or severely punished? At first glance it seems impossible, or at least very difficult to give an answer to these questions. However, for me, if I follow the logic of utilitarianism based on the maximization of profit, these questions pose no difficulty. My answer is as follows. The captain should not be arrested, punished or justified. There should be no trial at all. The crew involved in a disaster far beyond the borders of England could not and did not have any influence on the citizens of their country. Their actions could neither increase, nor reduce people's profit, or have any effect on the distribution of income in the society. The crew created their own small, isolated society, which had no interaction with the outside world. Therefore, it is the crew themselves who should decide which actions should be considered fair or not. It is also the crew themselves who should have established laws, rules and regulations by which their society should live. Citizens of England could have expressed their opinion on this story, but they had no right to judge them.

As I already mentioned in the discussion of the example of the dishonest sheriff, critics of utilitarianism very often forget that society maximizes benefits not because somebody sits down and calculates the total benefit, but simply because each and every individual strives towards this. If Sandel (2009) had taken this into consideration, he would have had much less difficulty with the discussion of the hypothetical example of the trolley car. Sandel proposes that each of us imagine we are the driver of a trolley car hurtling down a mountain with no brakes. On the tracks ahead you see five workers who do not notice the trolley car. Their death is unavoidable. Suddenly you notice a side track where there is only one worker. What should you do? Most people would prefer to turn onto the side track because in this case only one person will die. Although killing one innocent person is a tragedy, killing five people is even 
worse. When put like this, it is not too difficult for most people to make a choice. However, if we make things a little more complicated, we, for some reason, arrive at an entirely different decision. Imagine that you are standing on a bridge, under which a trolley car will pass. A trolley car with no brakes is racing along the tracks and at the end of the tracks there are five workers. You realise that these workers will certainly die, but suddenly you notice a very fat man beside you. You could push him off the bridge onto the track as the trolley car approaches. This man will die, but the five workers will be saved. You could throw yourself onto the tracks, but your body mass is clearly not sufficient to stop the trolley car. In this example, as in the previous example, you can sacrifice one person to save five. However, if you sacrifice one person in these slightly altered circumstances, public morality will clearly not be on your side. This comes as a surprise to many people. Why in the first case do social rules and regulations allow one person to be sacrificed, but in the second case they do not? What is the difference between these two examples? We can answer this if we do not forget that society consists of individuals seeking to maximize their profit. Together these individuals try to establish rules and regulations that enable each of them to achieve their own objectives. Therefore they will never agree to throw somebody off a bridge to save five workers. Any person will realise that if they approve such an act, tomorrow they could be the unfortunate victim being sacrificed. We all understand, of course, that we could also end up in the position of the workers. However, we believe the likelihood that we will be so careless, that we will work under such dangerous conditions and that we will be placed in mortal danger is far lower than the likelihood of simply walking around in a public place. We note that society will have nothing against a person who voluntarily throws themselves onto the tracks because a heroic act such as this does not oblige other citizens to jump onto a train track when somebody else is in danger. We do, of course, honour heroes and praise their actions, but nobody would ever blame a person who refuses to sacrifice themselves in order to save others. Why does public morality allow the death of one completely innocent person in the first example? Because the death of this person, or of the five workers is inevitable. Five workers will bring more benefits to society than one worker. Furthermore, the probability that any one of us could ever be in the place of the five workers is five times higher than the probability that we would be on the tracks alone. After all of these considerations, we can now easily alter the second example so that society not only approves the throwing of a person off the bridge, but also considers the citizen throwing the person onto the tracks to be a hero. In this case, we need the victim to be a person who is seeking to cause us harm and reduce our profits. To ensure that we do not incidentally become this person on the bridge, let the person be a member of a different and hostile rival society. And now let us imagine that we are in our hometown occupied by enemies. On the bridge stands our enemy. Society will support us even if we throw this enemy off the bridge onto the tracks when there is no trolley car. And if, in doing so, we save the life of five workers, we will be deemed a national hero.

Many respected authors who study issues of justice very often attempt to convince everyone, on the basis of examples that are both implausible and far removed from reality, that rational individuals are not capable of achieving an economically effective result. They argue that rational individuals must have certain ethical norms and moral principles in order for an economy to function effectively. In the standard version of a well-known experiment, people 
are asked to place a certain amount of money together into a single capsule, the contents of which increases by a certain factor, and then share out the money equally among all participants of the group. When everybody works together, each participant has a certain amount of profit. But this profit can be increased for one of the participants if they do not place money in the capsule and the others continue to do so. Normally, at the beginning of the game everybody tries to work together, but after a while certain players stop playing fairly and in the end everybody starts to cheat. This pattern of behaviour is often observed in monkeys (Chen \& Hauser, 2005). In my opinion, this sad result simply proves that the terms of the experiment were very far from real market conditions, where it is rather difficult to hide the profits of participants, where people have the ability to refuse to work with a fraud and where dishonesty can be punished. This is confirmed by studies conducted by Fehr \& Gachter (2000), which made a slight addition to the rules of the game. Participants were given the opportunity to punish those who refused to cooperate and acted dishonestly. In order to do so, they had to pay out of their own pockets, which they gladly did. The game players pay these temporary expenses in the knowledge that such a measure will help them earn profit in the future. After a while, the players began to behave fairly and even after a number of rounds they continued to place money in the capsule, which meant that each of them earned a stable profit for a long time.

The conditions proposed in the well-known game Prisoner's Dilemma are also far from real market conditions. When the game does not resemble the real market, its participants demonstrate non-cooperative behaviour. In a single-round game, when every player can make one single decision, after which the game immediately ends, the players very rarely attempt to cooperate with one another. This result is natural and is not surprising. Casual relations and unprepared deals often end in disappointment and deceit. They end up in deceit and even more often if every participant of the deal firmly believes that they will see their partner for the first and last time. However, if the conditions of Prisoner's Dilemma are made slightly more realistic and the players are invited to participate in a repeated multi-round game, they will definitely start to cooperate and maximize the total profit (Rapoport, 1991).

\section{Conclusion}

If we assume the main motives of human activity to be happiness, prosperity, satisfaction and lack of suffering, we have to admit that a science such as economics does not exist. Feelings, emotions, subconscious motives, internal stimuli and beliefs are in the realm of psychology. Psychology is therefore much more equipped to deal with the tasks placed upon economics, which confirms the constantly growing interest in recent years of economists towards the theories and methods of psychologists. There are, however, doubts regarding the prospects and capabilities of psychology, as today there is no clarity as to whether psychology is in itself a science (Hergenhahn, 2009).

Marx would call people who insist on such strange assumptions of economic theory complete idealists. In Marx's opinion, if a person believes that people's feelings create the material world around them and not the other way around, this person is an idealist. I agree with him on this point. We are all idealists if we believe that consciousness is primary and the material world is 
secondary. Idealists reject the primacy of existence and the material world and insist that only our consciousness and our feelings form the world around us. Idealists do not need science, there is no point in it. They need God. If we are not satisfied with this way of understanding the world, we will have to become materialists. Of course, the attempt made in the $19^{\text {th }}$ century to present the maximization of utility as the main motive for human behaviour did not change anything and did not make us become materialists. Utility is as immaterial and immeasurable as happiness. Today, the majority of economists would agree with this statement. The foundations of science cannot rest on such a dubious and uncertain concept. Therefore, we need to take one more step in the direction of materialism. If Marx was entirely logical, he would have undoubtedly come to the conclusion that our main aim is a desire for material benefit and material well-being. However, he never said anything like this (Fromm, 1961), despite the fact that it inevitably follows from his dialectical materialism. He could not allow himself to do so because such a move would destroy all of his own accusations of immorality in the free market and no theory of exploitation would be able to fix this. Marx himself was a complete idealist. However nothing is preventing us; we are able to make such a move and, moreover, we must make this move. To do this, we need most of all to get rid of the strange and entirely inexplicable division of people into producers and consumers, which for some reason, in the opinion of economists, should strive towards absolutely different goals. Undoubtedly, psychologists, who have now become our close friends, will serve as an invaluable aid as they explain why for such a long time economists have suffered from a split personality disorder. Seriously speaking, at present I see no reason to reject the statement that the main motive for human actions is their material benefit or, to put it simpler, profit. I have never come across, read or heard of any clear argument able to contradict this assumption. But this assumption changes a lot. The profit of an individual is completely material, measurable and comparable with the profit of another individual. This means that individuals can pay each other compensation, negotiate and enter into a social contract. Individuals can set an acceptable price for goods, based of course on the marginal profit from their use. Incidentally, this last point finally saved me from endless reflections and torment as to how consumers and producers, using the same product, determine the most effective method of using it.

Any person will be inclined to believe that anything that brings them profit is fair. We can easily see this for ourselves. Promotion at work, winning a contest, success, an opportunity to avoid a queue, an unexpected increase in price on something we have to sell and a reduction in price of something we have to buy - all of these are examples of events that we believe to be fair if they happen to us. However, people do not believe that everything that brings them profit is fair. For example, nobody will consider murdering a rival or setting their house on fire to be fair because if society supports such norms, next time we ourselves could become the target of violence. We support rules and norms of behaviour that not only allow us to receive profit, but also do not allow others to cause us harm. And if we are harmed, we justly seek to claim compensation. This is how ethics, morals and justice are established in a society.

We do not need a dictator to conclude a social contract in a democracy. Society is able to conclude a contract that enables the maximum total profit to be obtained and, as a result, the output of goods and services in that society will be maximized. If a certain law or norm offers 
an opportunity to obtain a total profit that is greater than the total losses, then it is likely that this law or norm will receive society's support. People who profit will be able to pay compensation to people who lose out and this level of compensation will exceed their losses and therefore the members of the society will unanimously vote for such laws and norms. If tomorrow there appears a new law which allows a higher total profit to be obtained and which requires the cancellation of the old law, society will cancel the old law and adopt the new law. The new law will, of course, be voted for unanimously. In this way, people's desire for profit will enable them to not only achieve an economic result, but also form fair institutions. People's desire for profit will enable us to not only build solid microfoundations for economic science, but also reinstate utilitarianism, which was so undeservedly cast aside.

The limit on the length of this paper does not allow me to fully address certain important issues of ethics, morality and justice, and many examples have remained unexamined. We could, for example, explain why in developed countries children care for elderly parents far less than in less developed countries, or why distant relations are stronger in poorer countries than in rich countries. We could prove that a fair society has to strive towards poor people becoming richer and not rich people becoming poorer. We could answer the question: how fair are citizens of developed countries when they ask migrants to observe the ethical norms in these countries and why is observing these norms of benefit to migrants themselves? However, without all of this I very much hope that the idea that justice prevails not when we embrace the greatest happiness or greatest felicity principle (Bentham [1789], 2005), but when we seek to maximize profit, does not seem so senseless to the reader. This is what I believe the main aim of the paper to be. And of course, in pursuing this goal, I never for a moment forget about my own personal profit.

\section{References}

Arrow, K. J. (1951). Social Choice and Individual Values. New York: Wiley.

Barro, R. J., \& Sala-i-Martin, X. (2004). Economic Growth. Second Edition. The MIT Press. Cambridge. London, England.

Becker, G. S. (2003). Human Behavior. Economic Approach. Selected Works on Economic Theory. Moscow. SU HSE. Rus. Trans.

Bentham, J. (2005). An Introduction to the Principles of Morals and Legislation. 1789. Latest Edition: Adamant Media Corporation.

Bernoulli, D. (1954). Exposition of a New Theory on the Measurement Risk. Eng. Trans. 1738. Econometrica. 22(1), 23-36. http://dx.doi.org/10.2307/1909829

Bilych, G. (2012). The Futility of Utility. Business and Economic Research. 2(2), 192-208. http://dx.doi.org/10.5296/ber.v2i2.2696

Braudel, F. (2011). Civilisation Materielle, Economie et capitalisme, XV-XVIII Siecle. Tome 1. Les Structures du Quotidien: le Possible et L`impossible. Armand Colin. Trans. Rus.

Chen, K., \& Hauser, M. (2005). Modeling Reciprocation and Cooperation in Primates: Evidence for a Punishing Strategy. Journal of Theoretical Biology. 235, 5-12. 
http://dx.doi.org/10.1016/j.jtbi.2004.12.015

Coase, R. (1988). The Firm, the Market and the Law. The University of Chicago Press.

Demsetz, H. (1967). Toward a Theory of Property Rights. American Economic Review. 57, 61-70.

Dworkin, R. (1977). Taking Rights Seriously. Cambridge. Mass.: Harvard University Press. 151.

Fehr, E., \& Gachter, S. (2000). Cooperation and Punishment in Public Goods Experiments. American Economic Review. 90(4), 980-994. http://dx.doi.org/10.1257/aer.90.4.980

Frey, R. (1984). Introduction: Utilitarianism and Persons. Utility and Rights. Ed. by R.G. Frey. Minneapolis: University of Minnesota Press. 15-20.

Fromm, E. (1961). Marx`s Concept of Man. Frederic Ungar Publishing: New York. 1-85.

Gauthier, D. (1985). Morals by Agreement. Oxford: Clarendon Press.

Gordon, S. (1980). Welfare, Justice, and Freedom. New York: Columbia University Press. 40.

Hare, R. (1981). Moral Thinking: Its Levels, Method and Point. Oxford: Oxford University Press. http://dx.doi.org/10.1093/0198246609.001.0001

Harsany, J. C. (1982). Morality and the Theory of Rational Behavior. Utilitarianism and Beyond. Ed. by A. Sen and B. Williams. Cambridge: Cambridge University Press. 39-62.

Hayek, F. A. (1993). Social or Distributive Justice. Justice. Ed. by A. Ryan. Oxford: Oxford University Press. 124.

Hayry, M. (1994). Liberal Utilitarianism and Applied Ethics. London and New York: Routledge. 79.

Hergenhahn, B. R. (2009). An Introduction to the History of Psychology. $6^{\text {th }}$ Edition. Wadsworth Publishing.

Kahneman, D., Knetsch, J. \& Thaler, R.H. (1986). Fairness as a Constraint on Profit-Seeking: Entitlements in the Market. American Economic Review. 76(4), 728-741.

Kramer, G.H. (1973). On a Class of Equilibrium Conditions for Majority Rule. Econometrica. 41, 285-297. http://dx.doi.org/10.2307/1913490

Leeson, P. T. (2009). The Invisible Hook: The Hidden Economics of Pirates. Princeton. Princeton University Press.

Machlup F. (1971). Theory of the Firm: Marginalist, Behavioral, Managerial. Microeconomics: Selected Readings. (Ed. By E. Mansfield). New York.

MacIntyre, A. (1984). After Virtue. Second Ed. Notre Dame: University of Notre Dame Press.

Mill, D. S. (1979). Utilitarianism. 1861. Indianapolis. Cambridge: Hacket Publishing Company. 
Moore, G. E. (1922). Principia Ethica. London: Cambridge University Press.

North, D. \& Thomas, R.P. (1973). The Rise of Western World: A New Economic History. Cambridge. Cambridge University Press. http://dx.doi.org/10.1017/CBO9780511819438

North, D. (2005). Understanding the Process of Economic Change. Princeton University Press.

Nozick, R. (1974). Anarchy, State and Utopia. New York: Basic Books. Inc. Publishers.

Payne, S.T. (2006). Utilitarianism as Secondary Ethic. Yale Divinity School. December 30. http://www.sethpayne.com/?page_id=145)

Rapoport, A. (1991). Prisoner`s Dilemma. In: The World of Economics. The New Palgrave. Ed. by J. Eatwell, M. Milgate, P. Newman. The Macmillan Press Limited.

Rawls, J. (1971). A Theory of Justice. Cambridge. Mass.: The Belknap Press of Harvard University Press.

Rothbard, M. N. (1977). Power and Market. Government and Economy. Institute for Humane Studies. Inc. Second Edition.

Samuelson, P. A., \& Nordhaus, W. D. (2004). Microeconomics. Eighteenth Edition. Irwin, McGraw-Hill.

Sandel, M. (2009). Justice: What's the Right Thing to Do? Farrar, Straus and Giroux.

Sandel, M. (2012). What Money Can't Buy. The Moral Limits of Markets. Farrar, Straus and Giroux.

Schneider, L. (1963). Preface to: K. Menger. Problems of Economics and Sociology. Urbana: University of Illinois Press. P. 16.

Sen, A. K. (1970). The Impossibility of a Paretian Liberal. Journal of Political Economy. 78, 152-157. http://dx.doi.org/10.1086/259614

Sen, A. K. (1999). Development as Freedom. New York: Knopf.

Shapiro, I. (2012). On Non-Domination. University of Toronto Law Journal. 62, 293-336.

Simon, H. A. (1971). Theories of Decision - Making in Economics and Behavioral Science. Microeconomics: Selected Readings. (Ed. By E. Mansfield). New York.

Walzer, M. (1983). Spheres of Justice: A Defense of Pluralism and Equality. New York: Basic Books. 314.

\section{Copyright Disclaimer}

Copyright reserved by the author(s).

This article is an open-access article distributed under the terms and conditions of the Creative Commons Attribution license (http://creativecommons.org/licenses/by/3.0/). 